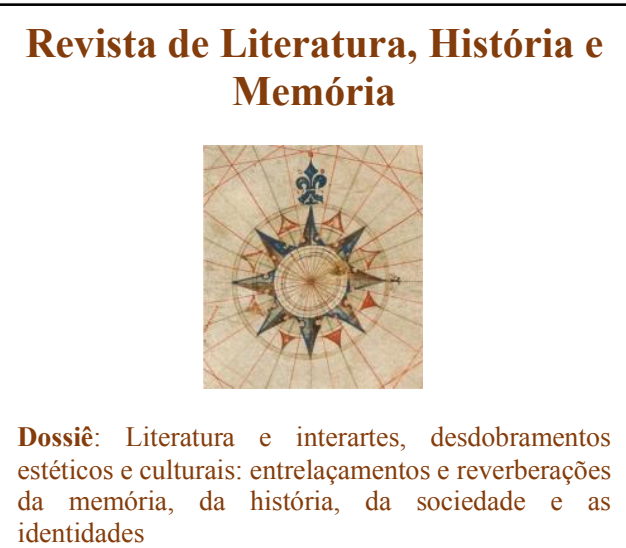

ISSN 1983-1498

VOL. 16 - No 28 - 2020

U N I O E S T E / CA S C A V E L - p. 171-190

\title{
IMAGENS E MEMÓRIAS DA DITADURA EM PONTOS DE FUGA: HATOUM PENSANDO O PASSADO E O ATUAL DESASTRE POLÍTICO BRASILEIRO
}

Images and memories of the dictatorship in Pontos de fuga: Hatoum thinking the past with the current brazilian political disaster

Marcos Douglas Bourscheid Pereira ${ }^{1}$

RESUMO: Este estudo tem como objetivo analisar as imagens da ditadura presentes na obra Pontos de fuga, de Milton Hatoum e, com base na análise das entrevistas do autor, verificar a intencionalidade argumentativa presente na crítica aos regimes de exceção, especialmente ao governo Jair Bolsonaro. O artigo perfaz o caminho da publicação, seu limiar histórico e as denúncias que a obra propõe, acerca da opressão e da violência da ditadura, visualizadas pelo autor como ecos que retumbam no presente político brasileiro por meio de elogiadores do período que se alçaram ao poder a partir do golpe ocasionado pelo impeachment de Dilma Rousseff, aliando passado e presente históricos. O aporte teórico da análise ocorre por meio das obras de Iser (1996); Bauman (2001); Said (2005 e 2007); Eagleton (2006) e Vieira (2007). Por meio de tais teorias buscase analisar os reflexos dos caminhos cíclicos da política mundial; a importância da ação dos intelectuais por meio de suas representações em defesa da democracia; o locus teórico da literatura de Hatoum; a interpretação por parte de seu leitor, além da estética da criação literária do autor.

PALAVRAS-CHAVE: Milton Hatoum; Pontos de fuga; Ditadura Militar; Memórias.

ABSTRACT: This study aims to analyze the images of the dictatorship present in Milton Hatoum's Pontos de fuga and, based on investigation in the author's interviews, to verify the argumentative intentionality present in the criticism of exception regimes, especially to the Jair Bolsonaro government, making up the path of publication, its historical threshold and the denunciations that the work proposes, about the oppression and violence of the dictatorship, visualized by the author as echoes that resound in the present Brazilian political through praisers of the period that rose to power from the blow caused by the impeachment of Dilma Rousseff, combining historical past and present. The theoretical contribution of the analysis occurs through the works of Iser (1996); Bauman (2001); Said (2005 and 2007); Eagleton (2006) and Vieira (2007). Through these theories, we seek to analyze the reflexes of the cyclical paths of world politics; the importance of the action of intellectuals in their representations in defense of democracy; the theoretical locus of Hatoum's literature; the interpretation by its reader, beyond the aesthetics of the author's literary creation.

KEYWORDS: Milton Hatoum; Pontos de fuga; Military dictatorship; Memoirs.

\section{ENGAJAMENTO POLÍTICO DE HATOUM: ENTRE A FUGA E A RESISTÊNCIA}

O autor amazonense Milton Assi Hatoum é um escritor brasileiro, de descendência

\footnotetext{
${ }^{1}$ Doutor em Letras pela UNIOESTE; Mestre em Letras pela UEM; Graduado em Letras Português/Espanhol pela UNIOESTE; graduado em Filosofia pela UNIPAR; Especialização em Metodologia de Ensino pela Faculdade São Judas Tadeu.
} 
libanesa, nascido em 1952 na cidade de Manaus. Sua história de vida pessoal confunde-se com os relatos mais belos dos romances de deambulação. Filho de pai libanês, casado com uma brasileira, teve em seu avô, o exemplo da migração à Amazônia brasileira, o que motivou a seu pai - por meio das fascinantes histórias ouvidas - a buscar, por meio de seu trabalho como funcionário diplomático do governo do Líbano, conhecer o local que povoava seus sonhos, alimentados pelas histórias ouvidas da boca do avô de Milton.

Arquiteto de formação, notabilizou-se como escritor, despontando-se como um dos ficcionistas brasileiros de maior presença no pódio de premiações no Brasil, nos últimos anos, alcançando diversos laureados também no exterior. Tantos prêmios, além de seu destaque por meio de obras de considerável repercussão resultaram na tradução de seus romances para cerca de oito línguas diferentes, tendo alcançado a tiragem de duzentas mil cópias de uma de suas principais narrativas, Dois irmãos (2000), publicada pela Companhia das Letras.

A obra de Milton Hatoum, composta por seis romances, além de um volume de contos notabiliza-se, especialmente quando a comparamos com suas entrevistas, pelo seu posicionamento crítico à sociedade e à política por meio de nuances que acompanham seus posicionamentos, seja em sua vida cotidiana, ou por meio da voz narrativa de suas personagens, ricas em complexidade ficcional.

Neste sentido, pensamos na importância do posicionamento e da atuação dos intelectuais na formação da opinião pública, além do rol de textos que podem ser por eles ofertados à sociedade, refletindo, por meio de tal mecanismo, acerca da complexa situação sócio-política enfrentada na contemporaneidade, no caso brasileiro, na contraditória reviravolta enfrentada pela democracia.

Sobre os acontecimentos mais recentes de nossa República, Hatoum reflete que:

Estamos num pântano, não podemos andar... Os três poderes são o que são, ou o que sempre foram. E labirinto... porque estamos perdidos... E o que é pior, perdidos e surdos. Não há vozes, só barulho...Todos falam ao mesmo tempo, ninguém se entende, ninguém escuta... É aí que surgem os oportunistas, os que dizem não ser políticos... Mas perigoso mesmo é um velhaco, saudoso da ditadura: o tenebroso deputado homofóbico, o apologista do estupro, da tortura, do ódio aos quilombolas e índios... E nada acontece... Não é incrível?" (HATOUM, 2018?).

A citação do autor esclarece o momento histórico captado. Apesar de referir-se ao engajamento político como algo perigoso, buscando evitar um possível enfraquecimento do 
romance $^{2}$, Hatoum demonstra ter se enveredado para as memórias do engajamento político face às angústias vividas pelo controverso impeachment de Dilma Rousseff; a assunção de Michel Temer e o iminente crescimento da figura polêmica do atual presidente da República, Jair Messias Bolsonaro. Tais reflexões nos alertam para o fato de que as vivências políticas repercutem naturalmente como eco da narrativa ficcional do autor por meio de nuances que mantém vivo o debate acerca dos perigos dos pensamentos primários que assombram a humanidade.

A memória do que foi por ele vivenciado em seus anos como estudante de arquitetura da UNB, os tempos vividos em São Paulo - onde acompanhou de perto e sofreu na pele a repressão da ditadura militar - e seu exílio na França, forneceram material importante para sua escrita, o que emerge na construção das suas personagens que compartilham das experiências que ele viveu e que valoriza em sua escrita. Sua intencionalidade evidencia uma preocupação com a manutenção da memória, com vistas que as atrocidades não sejam repetidas, como percebe-se em sua visão da obra pronta: "O pano de fundo continua sendo o da Ditadura Militar e eu quis também acentuar um pouco esse momento histórico que fez mal, mostrar como um estado repressor e bruto agia na vida das pessoas" (HATOUM, 2020).

A temática do romance em análise, Pontos de fuga (2019), e as imagens fortes da ditadura, são personificadas pelo protagonista Martim, que abordaremos neste artigo, parecem apontar para o que o autor já temia: a ascensão de um estado de repressão que tem evoluído de maneira assustadora no atual cenário político brasileiro.

Mesmo declarando-se lento em sua escrita, entendendo que a literatura deve conter um processo de maturação satisfatório e apesar do fato de que o autor tenha trabalhado, segundo seu relato ${ }^{3}$, por uma década, nos dois romances da trilogia ${ }^{4}, A$ noite da espera (2017) e Pontos de fuga (2019) - ambos já publicados - percebe-se em suas entrevistas e no teor do texto uma preocupação com a crescente onda que apontava para um retorno da repressão por meio da volta dos militares ao poder, como é observado nas ações do atual governo e na aclamação veemente de seus apoiadores pela ocupação dos militares em cargos importantes na estrutura

\footnotetext{
2 Segundo relatado em entrevista a Valentine Herold em 02 de fev. de 2020, disponível em: , https://jc.ne10.uol.com.br/canal/cultura/literatura/noticia/2020/02/02/milton-hatoum-uma-literatura-ideologicapode-enfraquecer-o-romance-398718.php $>$. Acesso em 22 de jun. de 2020.

3 Segundo relatado em entrevista a Valentine Herold em 02 de fev. de 2020, disponível em: , https://jc.ne10.uol.com.br/canal/cultura/literatura/noticia/2020/02/02/milton-hatoum-uma-literatura-ideologicapode-enfraquecer-o-romance-398718.php $>$. Acesso em 22 de jun. de 2020.

${ }^{4}$ A trilogia, segundo o autor relata em entrevistas, será completada com a publicação do terceiro volume, em 2020. Fala-se também, em algumas das entrevistas concedidas e em um bate papo com o Editor da Companhia das Letras, Luiz Schwarcz, na possível produção de um quarto romance, que se ocuparia em abordar melhor a vida do protagonista Martim.
} 
governamental civil, o que tem ocorrido de maneira sistemática nos últimos meses.

Mesmo que fugindo de rótulos polêmicos, Hatoum concorda que "talvez uma elite engajada seja necessária sim em momentos de extrema opressão como os que estamos vivendo nesse momento." (HATOUM, 2020). Tal reflexão aclara o fato de que o autor se posiciona criticamente em relação aos perigos dos regimes ditatoriais e de seu descaso com demandas importantes como a educação (o que é típico em governos que flertam com o totalitarismo). $\mathrm{O}$ autor relembra ainda que "foi também em Brasília que aconteceu 'o toque militar de recolher' [...]. A ditadura destruiu o projeto educacional de Darcy Ribeiro e Anísio Teixeira, frustrou todas as promessas de um futuro mais civilizado." (HATOUM, 2019b). Tal afirmação é reforçada pela fala do autor de que "O passado não deve ser esquecido" (HATOUM, 2019b), uma vez que o atual momento nos lembra as tristes sombras políticas do passado e remete às práticas atuais, pois considera que

É um absurdo. Esse governo se recusa a entender que o crescimento econômico sustentável depende do ensino e da pesquisa de qualidade. Durante a ditadura, a ameaça era física, e isso é abordado nos dois romances. Hoje, o corte de verbas destinadas à educação, as acusações descabidas e acintosas, e as ameaças nem sempre veladas têm como objetivo provocar uma morte lenta das instituições de ensino e pesquisa (HATOUM, 2019b).

A escrita de Hatoum também incorpora suas vivências à obra e, por meio das vozes narrativas, proporciona ao leitor um contato com sua experiência crítica por meio do enredo, proporcionando o alcance à complexidade do que o texto de Hatoum evidencia e o quanto o autor incorpora suas vivências às suas obras. Por meio das vozes narrativas, o leitor se aproximará dessa experiência e poderá alcançar a complexidade do viés político vivenciado pelo escritor. Essa ligação nos lembra o que Benjamim (1987, p. 228) afirma ser a classe menos favorecida socialmente hoje no país, pois "sujeito histórico do conhecimento é a própria classe oprimida" que, certamente, como nos apresenta o protagonista Martim, é a que mais sofrera com os movimentos políticos de 1964 e é a que mais será afetada nos dias de hoje com as políticas atuais em ação no país. Visto também que é a classe trabalhadora, representada no romance de formação de Hatoum, composta em sua maioria por estudantes que virá a ser a força motriz de trabalho retratada no romance que o autor promete lançar ainda em 2020, fechando a trilogia - a que tem maior possibilidade, seguindo a linha do pensamento benjaminiano, de se fortalecer como a classe de sujeitos revolucionários. Tal problemática demonstra a urgência da apresentação e da atuação daqueles que devem empreender a luta contra o sistema opressor que ciclicamente voltou à cena após as eleições 
presidenciais em 2018 no Brasil, no qual acendeu ao poder, por meio do voto, uma figura que prega a segregação, desvaloriza a luta de classes e o papel da mulher, em sua luta por direitos iguais, além de apoiar a violência policial e o estado de exceção.

$\mathrm{Na}$ seara explorada pelo romancista amazonense, a força da construção do narrador, marcante em todas as suas obras, se faz presente nas vozes narrativas que compartilham e alimentam o fôlego de Pontos de fuga, pois, como bem delineia Benjamin

É a experiência de que a arte de narrar está em vias de extinção. São cada vez mais raras as pessoas que sabem narrar devidamente. Quando se pede num grupo que alguém narre alguma coisa, o embaraço se generaliza. É como se estivéssemos privados de uma faculdade que nos parecia segura e inalienável: a faculdade de intercambiar experiências (BENJAMIN, 1987, p. 197-198).

Diante de fatos políticos tão conturbados, a figura do narrador se apresenta como algo urgente e indispensável em um romance, alertando-nos para a importância dos fatos narrados e para as narrativas da vida cotidiana, que nos trazem importantes experiências que devem servir como aprendizado. Tais experiências conferem força aos fatos políticos sacramentados, que causavam horror à sociedade brasileira e que hoje parecem ter sido esquecidos, reacendendo nas páginas do romance de Hatoum, a urgência da reflexão sobre os horrores que estão por vir caso nada seja feito. Como afirma o autor: "Como escritor de ficção, estou mais preocupado com o passado e sua repercussão no presente" (HATOUM, 2020c). Tal preocupação, inevitavelmente, desemboca na arte, que reflete a vida e demonstra o engajamento da obra literária, relembrando tristes páginas da história que pareciam ter sido superadas.

\section{PONTOS DE FUGA, DE MILTON HATOUM}

Nove anos após a publicação do romance Órfãos do Eldorado (2008), quarto romance do autor, Milton Hatoum lança ao público o primeiro livro da trilogia a que fazemos referência neste trabalho, que trata de um dos temas mais marcantes de sua vida: a ditadura militar, que lhe traz sofrida lembrança. O primeiro volume da trilogia, A noite da espera (2017), narra a história do jovem Martim, em Brasília, no mês de janeiro de 1968, cidade na qual ele, vivendo com seu pai, Rodolfo, recém divorciado, cursa a faculdade de Arquitetura da UNB (Universidade Nacional de Brasília). A mudança de cidade ocorre em meio ao traumático distanciamento de sua mãe, Lina, que abandonou o marido para viver uma história 
de amor com um artista.

Ao chegar à cidade recém-construída, Martim inicia uma amizade com um grupo bastante eclético, que inclui Fabius - filho de um embaixador chamado Faisão (perseguido pela ditadura) e sua namorada, chamada Ângela. Ele também se relaciona com Dinah, que vem a ser sua namorada (e por quem sofre, como vemos no romance seguinte, devido à separação, causada por conflitos pessoais e políticos); a personagem Nortista - fortemente perseguida pela ditadura; Vana e Lázaro (residente em uma cidade-satélite de Brasília).

Durante os cinco anos que vive na capital federal, Martim realiza frenéticas anotações que relatam sua vida de estudante no colégio e na universidade. Narra as imagens turbulentas da perseguição política e os anseios pelo reencontro com a mãe, sofrendo com uma atmosfera de dúvidas, tensões emocionais e violência. Ao final da narrativa, em um clima de hostilidade política, Martim foge para São Paulo, abandonando seu amor da juventude, Dinah, a expectativa de rever sua mãe e a esperança de ver vivos seus amigos, presos pelo regime militar, que também o persegue.

Guardadas as devidas proporções que cabem ao debate dos romances autobiográficos e o processo de seleção e combinação que compõe o processo de produção artística da Literatura, o romance traz traços fortes das experiências de vida do autor, que já declarara em entrevista $^{5}$ que - aconselhado por amigos que leram sua obra - os melhores romances nascem das experiências guardadas ao longo de anos. Assim como o autor, no campo literário que foge das questões autobiográficas, a personagem vive uma frenética busca por sua mãe, Lina, que se retirara da vida do jovem de maneira abrupta.

$\mathrm{Na}$ linha do romance que se assemelha a um Bildungsroman, o segundo volume Pontos de fuga (2019), traz a sequência da história, quando Martim vai a São Paulo, refugiase em uma República na Vila Madalena, juntamente com outros alunos da USP (Universidade de São Paulo) e vive as angústias do encerramento de seu relacionamento com Dinah e os insucessos da busca pelo paradeiro de sua mãe.

O romance é composto por um processo que tem sido utilizado amplamente na contemporaneidade que é o da composição narrativa realizada por diversas vozes narrativas, que são enxertadas em gêneros diferentes de escrita (diários e cartas). O ponto forte da obra é a deambulação da personagem Martim, que vive diversas aventuras, angústias, passa pelo cárcere, vê amigos desaparecerem e enfrentarem (da mesma maneira que ele) a experiência da

\footnotetext{
5 Entrevista concedida por meio de live no perfil do Instagram https://www.instagram.com/miltonhatoum_oficial/?hl=pt-br, realizada no dia 18 de junho de 2020, entre as 19:00 e as 20:00.
} 
prisão, revelando de maneira bastante diluída, os horrores da ditadura militar no Brasil que se iniciou em 1964 e persistiu até meados dos anos 1980, ceifando milhares de vidas e a liberdade do povo brasileiro, refletindo a preocupação do autor:

\begin{abstract}
Muitos leitores e críticos viram isso, foi um paralelismo totalmente involuntário de minha parte. Não pensei que fosse acontecer esse retorno do autoritarismo tão bruto, pensei essa trilogia há mais de dez anos. No fundo, não nos livramos da herança da ditadura. Mesmo no período que considero mais significativo da democracia, que foram os governos do FHC e do Lula, e vejo coisas positivas nos dois, o Brasil não teve, como no Uruguai, na Argentina e no Chile, o compromisso democrático de eliminar os resquícios da ditadura. O inimigo dessa extrema direita ainda é o comunismo, olha que loucura. Essa extrema direita tem pautas da ditadura, como fechamento do Congresso, do Supremo, o fim das liberdades, é uma coisa espantosa. É uma nostalgia obscura de uma época que não foi, de fato, resolvida. Não colocamos uma pá de cal. O Bolsonaro despreza 50 mil mortos da pandemia, a sensibilidade dele não existe em relação a isso (HATOUM, 2020, b).
\end{abstract}

O paralelismo, ainda que involuntário, surge de uma preocupação crescente e que esbarra em elementos históricos que não deixam a obra sobreviver como um objeto artístico pensado apenas no passado histórico do autor ou da nação. Elementos da perseguição do atual presidente às ações que sempre foram compreendidas como práticas razoáveis, ligadas a um estadista, unem o passado ao presente, denotando elementos trazidos pelo autor como exemplos negativos que deveriam estar presentes apenas na memória, mas que, fatalmente, encontram-se presentes na atualidade da política nacional.

\title{
A ATUAL DITADURA CIVIL E O PARALELISMO COM A OBRA
}

O segundo volume da trilogia O lugar mais sombrio, inicia-se com o diário de Martim, do ano de 1972. Tal período já abarcava os fatos ocorridos com o jovem em Brasília e sua mudança para São Paulo, vivendo os reflexos de oito anos do golpe militar de 1964. Ainda que Hatoum declare que não há paralelismo intencional entre o período violento dos anos 1960/70 e as atrocidades que crescem por meio do sistema de governo em 2020, a obra ganha corpo e significação enquanto linguagem viva na atualidade, como nos lembramos ao ler o crítico literário inglês Terry Eagleton, que observa o potencial do texto ficcional: "Talvez a literatura seja definível [...] porque emprega a linguagem de forma peculiar [...] nas palavras do crítico russo Roman Jakobson, representa uma 'violência organizada contra a fala comum"” (EAGLETON, 2006, p. 03).

A "fala comum", como observa o formalista russo, é desafiada e reinterpretada com 
textos como o de Pontos de fuga, que trazem à tona a lembrança (aos que se esqueceram) e imagens históricas - ainda que por meio do texto ficcional - (aos que negam a existência do totalitarismo). Congregando ficção e realidade - como se imagina acerca dos processos literários de seleção e combinação, na visão de Iser (1996) - podemos afirmar que o olhar depositado sobre a narrativa e os sofrimentos de Martim representam mais do que simples objeto literário em tempos tão sombrios como os de hoje, lembrando a referência de Eagleton (2006, p. 12), que pontua que: “A definição de literatura fica dependendo da maneira pela qual alguém resolve ler, e não da natureza daquilo que é lido". Desta forma, a leitura do romance de Hatoum nos transporta aos anos de chumbo da ditadura militar, sem, no entanto, nos apartar do ato de traçar paralelos com a "militarização" do governo brasileiro e da catástrofe que isso pode representar na atualidade.

$\mathrm{O}$ texto de Hatoum ainda nos remete à reflexão de que "Um segmento de texto pode começar sua existência como história ou filosofia, e depois passar a ser classificado como literatura; ou pode começar como literatura e passar a ser valorizado por seu significado arqueológico "(EAGLETON, 2006, p. 13). Tal afirmativa nos proporciona um movimento para o passado além de deslocar a preocupação para o futuro a partir do que a obra literária pode representar: uma catarse, porém sem deixar de emitir um alerta.

Em Pontos de fuga a imagem do que hoje se apresenta como a figura dos conservadores que comandam o país pode ser observada na descrição de Martim ao relatar como a personagem via seu novo patrão (um construtor de Brasília que o emprega como físcal de obra): "Suor no rosto amarelado do homem, uma Bíblia aberta ao lado do travesseiro; presa a um gancho de aço na parede, uma bandeira brasileira de cetim roçava o assoalho. A luz da tarde, filtrada por uma cortina verde encardida [...] (HATOUM, 2019, p. 40)”. Como podemos observar no atual estado da democracia brasileira, o slogan "Brasil acima de tudo. Deus acima de todos", que, segundo Aranda (2018), reforça o ethos de enviado por Deus, apropriado pelo atual presidente, é representado na narrativa de Hatoum pelo elo entre a bandeira nacional e a bíblia: companheiros inseparáveis dos conservadores herdeiros do golpe militar de 1964 e dos atuais mandatários nacionais, que usam tais símbolos como modelo de sua política patriarcal e opressora.

O elo entre a época representada no romance e a atualidade política nacional converge também com a análise da política mundial e os interesses das classes dominantes, que disfarçam suas intenções com falácias sobre o progresso, como observa Bauman (2001, p. 12):

[...] a tarefa de construir uma ordem nova e melhor para substituir a velha 
ordem defeituosa não está hoje na agenda — pelo menos não na agenda daquele domínio em que se supõe que a ação política resida. $\mathrm{O}$ "derretimento dos sólidos", traço permanente da modernidade, adquiriu, portanto, um novo sentido, e, mais que tudo, foi redirecionado a um novo alvo [...]. Os sólidos que estão para ser lançados no cadinho e os que estão derretendo neste momento, o momento da modernidade fluida, são os elos que entrelaçam as escolhas individuais em projetos e ações coletivas — os padrões de comunicação e coordenação entre as políticas de vida conduzidas individualmente, de um lado, e as ações políticas de coletividades humanas, de outro.

Os defensores dos encaminhamentos repressores estão presentes, quase ciclicamente, ao longo da história, como podemos observar na atuação de um pequeno grupo denominado “300 do Brasil"’. Tais grupos são lembrados na narrativa, evidenciando o paralelismo das ações dos grupos repressores: "Mas há grupos políticos mais execráveis e muito mais violentos [...] Por exemplo, o CCC... [...] É um dos demônios brasileiros...Um grupo paramilitar, as milícias da pátria armada" (HATOUM, 2019, p. 55). Da mesma forma como a narrativa aponta, os destinos das nações são decididos, na maioria das vezes, por negociatas que utilizam as formas de opressão e repressão mais diversas para se fazer valer as vontades de grupos pequenos, porém poderosos, por meio de ações duvidosas e disfarçadas:

A dúvida se torna um círculo vicioso. Com a arte de negociar interesses comuns e destinos compartilhados caída em desuso [...] e com a ideia de "bem comum" [...] sendo marcada com as marcas da suspeita, da ameaça, da nebulosidade e da tolice, a busca por segurança em uma identidade comum ao invés de em um acordo de interesses comuns - emerge como a mais sensata, efetiva e produtiva maneira de proceder; porém, as preocupações com a identidade e suas defesas contra a poluição fazem da ideia de interesses comuns [...] a mais incrível de todas e também a mais fantástica, sendo a habilidade e a vontade para persegui-las, as características menos prováveis de aparecerem. (BAUMAN, 2001, p. 106).

A representação, na literatura de Hatoum, é realizada por meio de reflexões acerca dos motes que motivam o ideal de nação pregado pela elite conservadora, como quando o protagonista do livro cita a motivação para a construção de Brasília: “A grande inspiração do projeto da capital é o desenho da cruz. Religião e razão, monsenhor San, como se Brasília fosse uma cidade perfeita, concebida pelo sopro do Espírito Santo" (HATOUM, 2019, p. 68), aliados ao fato de que a religião fundamenta a base para o futuro econômico, como é disseminada a ideia atualmente e era durante a Ditadura Militar, também retratada na obra,

\footnotetext{
${ }^{6}$ Informações sobre o grupo circulam em diversas reportagens de amplitude nacional, como na reportagem do site UOL. Disponível em: < hhttps://noticias.uol.com.br/cotidiano/ultimas-noticias/2020/06/15/o-que-e-300-dobrasil-grupo-de-extrema-direita-liderado-por-sara-winter.htm $>$. Acesso em 13/07/2020.
} 
que cita a miscigenação nacional e seu paradoxo com ideias eugenistas "Sergio Sansei, sofísta oriental, mas com índole e cabeça mestiços. Defensor da ordem e do progresso, apontados para o futuro, essa palavrinha enganosa, de alta periculosidade...” (HATOUM, 2019, p. 69).

A obra de Hatoum perfaz profundamente também uma crítica a respeito da tensão da modernidade, que vive o risco da perda da democracia, a partir do olhar sábio acerca da sociedade, realizado pelo autor, e também a partir da voz conferida às personagens, que o fazem por meio da figura do observador, que visualiza na rua o campo para suas elucubrações, tendo como ponto de partida o que vê concretamente, como descreve Benjamin $(1989$, p. 35)

\begin{abstract}
A rua se torna moradia para o flâneur que, entre as fachadas dos prédios, sente-se em casa tanto quanto o burguês entre suas quatro paredes. Para ele, os letreiros esmaltados e brilhantes das firmas são um adorno de parede tão bom ou melhor que a pintura a óleo no salão do burguês; muros são a escrivaninha onde apoia o bloco de apontamentos; bancas de jornais são suas bibliotecas, e os terraços dos cafés, as sacadas de onde, após o trabalho, observa o ambiente.
\end{abstract}

Assim como o flâneur, citado por Benjamin, uma das personagens de Pontos de fuga observa a rua e sua aflição, destacando a dor contida na visualização a partir de cenas que desafiam o estabelecimento da democracia: "Um policial espancava um menino na porta de um boteco, mãos pequenas e escuras foram algemadas, o detido foi empurrado para dentro de uma viatura, a roda de curiosos se desfez" (HATOUM, 2019, p. 151). Neste ínterim, como delineia Benjamin (1987, p. 226): "a tradição dos oprimidos nos ensina que o 'estado de exceção' em que vivemos é na verdade a regra geral". Tal regimento emerge por meio de ciclos, como ensina Bauman (2000), que se sucedem e retornam (ou saem das sombras onde se escondiam) sob o signo do horror e saltam de 1964 para 2020 sob novas e preocupantes estratégias governamentais. O próprio autor descreve tal situação observando que

é provável que certas sociedades sejam mais humanizadas. Refiro-me a nações com democracia estável e instituições sólidas, cujos cidadãos - dos mais pobres aos mais ricos - são protegidos pelo Estado do bem-estar social. Nações em que as Forças Armadas apenas cumprem seu papel institucional e jamais se intrometem na vida política, muito menos para tutelar, com alianças cúmplices, governos autoritários, sem qualquer compromisso com a democracia (HATOUM, 2020c).

A obra de Hatoum traz a reflexão, por meio da visão das personagens, acerca dos horrores da Ditadura, e também aos procedimentos de negociação com os opressores que 
favorecem seu retorno ao cenário político, como refletem vozes que são citadas no romance e bradam: "Anistia para torturadores e assassinos? [...] É essa a reconciliação nacional? Você quer saber o que os torturadores fizeram comigo e com os meus amigos?" (HATOUM, 2019, p. 240-241). Na linha de sua preocupação política, o autor pontua que: "Nos outros países da América do Sul, os generais foram julgados, e vários foram presos. Aqui, com a anistia geral, o aparelho repressor do Estado ficou incólume, latente, pronto para voltar - como voltou. Aquilo foi um erro" (HATOUM, 2019a).

Sob o aspecto da intencionalidade literária possível na obra de Hatoum, poderíamos recorrer à pré-linguística de Husserl e inferir que Hatoum - que em suas entrevistas afirma fugir do conteúdo político engajado em sua literatura, apesar de dizer que estamos vivendo no Brasil o pior momento político de sua história ${ }^{7}$ - intenciona marcar em sua obra o sentido do perigo que sofre a democracia com o que propõe a política brasileira na atualidade, entendendo que "O sentido é algo que o autor quer; é um ato mental, espiritual, que é então "fixado" para todo o sempre através de uma série particular de sinais materiais" (EAGLETON, 2006, p. 103). Porém, pode-se refletir também que a intencionalidade do autor dialogaria com o que Eagleton observa da teoria de Heidegger de que

aquilo que a obra nos "diz" dependerá, por sua vez, do tipo de perguntas que somos capazes de lhe fazer, dependerá de nosso ponto de vista na história. Dependerá também de nossa capacidade de reconstruir a "pergunta", pois a obra é também um diálogo com a sua própria história [...] O presente só é compreensível em função do passado, com o qual forma uma viva continuidade; e o passado é sempre apreendido de nosso ponto de vista parcial dentro do presente. O entendimento ocorre quando nosso "horizonte" de significados e suposições históricas se "funde" com o "horizonte" dentro do qual a própria obra está colocada (EAGLETON, 2006, p. 109).

O leitor esperado por Hatoum, e que receberá sua obra, muitas vezes refletirá sobre os pontos trazidos pelas vozes narrativas das obras e os sofrimentos sociais causados pelo momento político imposto pela ditadura. É possível que a influência que eclode na mensagem deixada por Hatoum represente a iminência da volta dos tempos sombrios, por meio de um autoritarismo político que ameaça a frágil democracia brasileira e nos leva ao engajamento, como sugere o autor:

Não só eu, mas muita gente, gostaria de ir às ruas, de me mobilizar

\footnotetext{
7 Reflexão presenta na Entrevista a Paulo Moreira Leite, do Brasil 247, disponível em: $<$ https://www.youtube.com/watch?v=aoARVzg7ggE\& feature=share\&fbclid=IwAR2aY1n0VLxQvpFRukdU6d7 y37ff7-rQQHYWCzRnvnEtbfE6-U WfNqBVVE>. Acessado em 14/07/2020.
} 
fisicamente neste momento, mas não podemos, porque não somos irresponsáveis. Não está fácil. O Brasil talvez seja o único lugar do mundo onde o governo é incapaz de lidar tanto com a pandemia quanto com a democracia (HATOUM, 2020a).

Neste sentido, a obra Pontos de fuga traz elementos importantes de reflexão para subsidiar o leitor acerca da necessidade da recordação (para que não se desmorone ao esquecimento) das atrocidades que ameaçam o país. Sobre o processo de construção da obra literária, Eagleton pontua que:

Todo texto literário é construído a partir de um certo sentimento em relação ao seu público potencial, e inclui uma imagem daqueles a quem se destina: toda obra encerra em si mesma [...] um "leitor implícito"; inclui em todas as suas atitudes o tipo de público que prevê (EAGLETON, 2006, p. 127).

O "leitor implícito" de Hatoum tem como destino final a luta contra as atrocidades do radicalismo fascista e a violência que ela propõe. A publicação dos dois primeiros livros da trilogia do autor, produzidos como um romance de formação brasileiro, trazem em seu bojo tanto as vivências do autor - em seus anos de crescimento e amadurecimento sob a opressão da Ditadura Militar - quanto aos ensinamentos aos mais jovens e as reflexões a leitores de todas as idades sobre os perigos dos atuais grupos dominantes da política brasileira dos anos 2020. Como pontua:

enquanto durar o atual governo, que alimenta perversamente o atual estado catastrófico. Não encontro qualquer razão para ser otimista, se é que fui algum dia. E a esperança, para não ser uma mera palavrinha de consolo, só fará sentido se houver uma forte mobilização de todos os brasileiros que anseiam por uma verdadeira democracia para este país. Espero que os jovens usem toda sua energia - física, moral e intelectual para, nos limites da democracia e do Estado de direito, fazer mudanças positivas e duradouras. Só assim poderemos emergir desse "mundo em escura sofreguidão" (HATOUM, 2020c).

Unindo passado e futuro, a partir das preocupações do autor que motivaram sua produção em Pontos de fuga, a personagem Martim (que amadurece ao longo do romance de formação de Hatoum) analisa, tal qual o autor faz atualmente, a aventura liberal desastrosa no Brasil:

Aqui, os falsos liberais imitam Brás Cubas, apenas trocaram a Universidade de Coimbra pela Escola de Chicago. Repetem os vícios da personagem do Machado, apoiam a ditadura, a tortura, a censura, e fazem negociatas com empresas do governo, políticos e militares. Liberalismo com terror de 
Estado, a receita chilena do criminoso Pinochet e sua gangue (HATOUM, 2019, p. 244).

A crítica faz parte do rol de elucubrações do autor acerca do processo de condução da política brasileira, secularmente associado aos desígnios das elites nacionais. A caricaturização da elite "liberal" brasileira aponta para a hipocrisia e desvalorização que a massa de intelectuais nacionais alerta: a necessidade da solidariedade e de uma democracia que atenda a todos, o que é imediatamente oposto aos horrores da censura, das ditaduras e do militarismo no poder. Assim, Hatoum assume o papel do intelectual concebido por Edward Said, o que evidencia a importância do combate, por meio de sua voz e literatura, a oposição à volta de qualquer modelo de ditadura:

O papel do intelectual é, num modo dialético, oposicionista, revelar e elucidar a competição [...] desafiar e derrotar tanto um silêncio imposto como a quietude normalizada do poder invisível em todo e qualquer lugar e sempre que possível. Pois há uma equivalência social e intelectual entre essa massa de interesses coletivos dominadores e o discurso usado para justificar, disfarçar ou mistificar as suas operações, prevenindo ao mesmo tempo as objeções ou questionamentos que lhe são feitos (SAID, 2007, p. 164-165).

Tal papel, assumido pelo autor, surge das vozes evidenciadas no romance Pontos de fuga. Uma das reflexões propostas pelo autor mostra como a imagem dos símbolos da ditadura se apagara, como a própria aceitação do sistema:

Num cartaz pregado num tabique, ainda era possível ler "Brasil: Ame-o ou Deixe-o" acima da fotografia colorida e meio apagada do busto do general Médici; as cores da bandeira brasileira na faixa presidencial haviam sumido, e no rosto militar apenas a boca entortada e as sobrancelhas espessas apareciam no papel sujo (HATOUM, 2019, p. 248).

As imagens refletidas na observação de Martim, trazem à tona o apagamento da força do regime ditatorial, evidenciando os resquícios suscitados pelo lema militar, a fotografia desbotada e a sujeira do papel. As marcas textuais remontam à visão do autor, que declarou que a volta do sistema opressor ao poder no país fora propiciada pela falta de julgamento ocasionado pela lei da anistia nacional e pela permanência de aparelhos ideológicos do Estado como a Polícia Militar, em detrimento de um regime civil de policiamento comunitário no país.

Intelectuais como Leonardo Boff também demonstram sua preocupação ${ }^{8}$ ao ressaltar

8 Conforme relatado em entrevista. Disponível em: <https://www.youtube.com/watch?v=-oEn3iPhMSY>. 
que o atual presidente da República, Jair Bolsonaro, se diz arauto dos mais violentos generais da ditadura, quando afirma que deveria ter matado figuras importantes em sua "limpeza" proposta ao país. Tais declarações demonstram o quão preocupante é o cenário (quando um líder nacional conclama seus cidadãos à violência) e reforçam a importância de obras como as de Hatoum.

Outro ponto relembrado pelo autor em suas entrevistas e tema constante de seus livros é a relação dos indígenas com a civilização imposta pela colonização nacional europeia. A falta de políticas públicas e a anulação de direitos abre as portas a um novo genocídio indígena patrocinado pelo atual governo. Previsão tal consumada atualmente e que já trazia preocupações a Milton Hatoum. Em Pontos de fuga, há a denúncia quanto à situação por meio do questionamento de Laísa, personagem amiga do protagonista Martim: "será que num futuro próximo os nambiquaras vão sobreviver à catástrofe? Ou seremos nós, os brancos, as vítimas da 'missão civilizadora'?” (HATOUM, 2019, p. 261). A reflexão quanto aos povos nativos está presente também na preocupação de Lévi-Strauss, inserida na obra: "Tão perto de mim quanto uma imagem no espelho, eu podia tocar neles, mas não podia compreendê-los" (HATOUM, 2019, p. 262). O limite da compreensão, enfrentado pelas personagens em processo de maturação, exalta os perigos da exposição do preconceito, nas ações perigosas de governantes opressores. Quando até os jovens conscientes e preocupados com as causas das minorias se questionam acerca de seu próprio limite de compreensão, o que pensar então de governantes opressores, ligados a ideais fascistas e eugenistas? Sobre a questão da ideia de uma nação homogênea, Said (2005) reflete:

Quanto ao consenso de uma identidade de grupo ou nacional, o dever do intelectual não é mostrar uma entidade natural ou divina e sim um objeto construído, fabricado, às vezes até mesmo inventado, com uma história de lutas e conquistas em seu passado e que algumas vezes é importante representar (SAID, 2005, p. 44).

A obra desafia a construção da política atual e suas ambições de pátria homogênea e "limpa" quando traz à reflexão a cultura daqueles que foram perseguidos, exterminados e propõe debates que aproximem o público de bandeiras importantes das minorias, levando o leitor a uma catarse provocada pela criação do cenário que demonstra a beleza da cultura indígena, como verifica-se na narrativa, por meio da observação realizada pela personagem Laísa: 
Os casais se abraçam com força, como na nostalgia de uma unidade perdida; os carinhos não são interrompidos pela passagem do estrangeiro. Percebe-se em todos eles uma imensa gentileza, uma profunda leveza espiritual, uma ingênua e encantadora satisfação animal, e, reunindo esses sentimentos diversos, alguma coisa como a expressão mais emocionante e verdadeira da afeição humana (HATOUM, 2019, p. 265).

As causas que envolvem as minorias, como percebe-se na preocupação do autor e das suas personagens, que expõem na vitrine da obra sua formação e as experiências que vivem, evidenciam a preocupação de Hatoum com o caminhar cíclico da política e do progresso do povo brasileiro. $\mathrm{Na}$ atualidade, em meio ao contexto de pandemia que abalou as estruturas sociais e econômicas da humanidade, o autor comenta que seu romance, pensado desde os anos 1980, observou o percurso do amadurecimento em sua mente dos fatos que o compõem, experimentando de maneira triste a volta da repressão, culminada, em suas palavras ${ }^{9}$, com uma triste coincidência em relação à sua obra. É constante a preocupação e a proatividade do autor, que declara:

Tento fazer o possível, mas meu raio de ação é limitado. Tento prestar solidariedade aos mais necessitados, às pessoas que estão muito vulneráveis. Fiz algumas parcerias com editoras, inclusive uma de $\mathrm{BH}$, a Páginas. A Leida Reis vai publicar um livreto de sete crônicas, e doei os direitos autorais. Uma parte das vendas vai para ONGs da Amazônia. Este é o momento de fazer parcerias com livrarias de rua, que estão passando por um período difícil. A gente sabe que o alcance é muito pequeno, mas são milhares de pessoas fazendo isso. Não é por acaso que todo o sistema opressivo persegue artistas e escritores. Desde sempre foi assim, desde a Roma Antiga. O poder tem medo da imaginação, da liberdade, que perturba o pensamento autoritário, em bloco. O presidente Bolsonaro não consegue resolver a coisa da cultura. São cinco secretários em um ano e meio, acho que nunca aconteceu isso na nossa história republicana. Ele aboliu o Ministério da Cultura, ele sabe que a cultura é uma ameaça a ele. Nós não devemos ter medo, tenho medo é do vírus, mais pelos meus filhos, mas medo de enfrentar essa gente eu não tenho. Já passei pela ditadura, já fui preso (HATOUM, 2020b).

A disposição em observar as questões culturais e políticas da nação, não de uma forma acomodada, mas com interesse em provocar reflexão e mudanças de paradigma está presente tanto em suas entrevistas como na voz de suas personagens. O passado e o presente se encontram no olhar do autor e reflete suas personagens e vivências, sugerindo uma proximidade histórica entre os anos 1960 e 2020. O autor observa, por exemplo que "Nenhum desses ministros aí citou uma obra literária que seja. A única obra citada pelo presidente é o

\footnotetext{
9 Conforme relatado pelo autor em entrevista à Tutaméia TV. Disponível em:
} $<$ https://www.youtube.com/watch?v=6R6RetkE0d4>. Acessado em 18/07/2020. 
livro de um torturador" (HATOUM, 2020a). Fazendo referência à tortura, em Pontos de fuga, as vozes narrativas dão conta de que "Interrogatório policial é uma escravidão, a violência das palavras, dos ferros e choques. Fui detido duas vezes, só porque sou o que sou, um brasileiro qualquer, sem a porra de um diploma, sem pinta de bacana” (HATOUM, 2019, p. 275). Assim, o alinhavar das práticas de tortura, da sua repulsa e dos tempos dos quais não se deve esquecer, para não se repetir, unem passado e futuro, justificando a intenção do autor em provocar reflexão sobre o ciclo triste que parece não ter fim. Debates em mesa de bar, como o relatado pela personagem Julião, dão o tom que o autor deseja fixar na mente do leitor, que, coincidentemente ou não, vê na política repressora atual a representação do horror e dos perigos que rondam o fato de se ter o país governado por um presidente controverso como Bolsonaro. Julião descreve que:

Dois caras tomavam uma cachacinha no balcão, levavam um papo sobre o presidente Geisel. "Esse general é um democrata, vai devolver o poder pros civis." [...] "Democrata o caralho, larga de ser ingênuo, meu. Em abril esse general fechou o Congresso. E no fim do ano passado vários comunistas foram executados numa casa lá na Lapa. Desde abril de 1964 estão prendendo e matando tudo que é opositor, até índios e militares. Agora o pau tá comendo entre dois bandos de milicos da pesada...Tem muito coronel e general que não querem entregar a rapadura" (HATOUM, 2019, p. 276).

Como se observa nas palavras de sua personagem, a opressão e a perseguição dialogam com o principal objetivo, que é a manutenção do poder por parte daqueles que, pelos meios democráticos, dificilmente se sustentariam por muito tempo. Apesar de tal emblemática, Hatoum relata em entrevista ${ }^{10}$, que sua meta é permanecer no Brasil, e, ainda que na presença do atual contexto político e social, como observou, com base da obra Dois irmãos, Estela J. Vieira, o autor preserva o ideal de que:

Certas amizades mostram que a religião, as crenças espirituais ou o interesse intelectual, podem unir pessoas de diferentes raças e culturas. O deslocamento não consiste apenas nos imigrantes ao Brasil, mas também na situação da Amazônia com respeito ao resto do país, e dos indígenas dentro da própria cidade de Manaus. Expor estes problemas é uma forma de referirse a certas teorias pós-colonialistas já que o autor mostra que deste contacto forçado entre culturas, língua e religiões diferentes, nascem formas alternativas de compreensão (VIEIRA, 2007, p. 176).

Neste ponto, as reflexões de Hatoum apontam, como se observa em suas entrevistas,

10 Conforme relatado pelo autor em entrevista à Tutaméia TV. Disponível em: $<$ https://www.youtube.com/watch?v=6R6RetkE0d4 $>$. Acessado em 18/07/2020. 
para a importância do olhar para os exemplos de práticas advindas do pós-colonialismo e para o resultado do progresso dos países sul-americanos em seus processos de encerramento das ditaduras e governos repressores. Para tal, o autor recorre a personagens como Julião, que traz a impactante fala acerca da dor causada pela tortura à personagem Dinah: "Sentia a morte dentro de mim, e em vários momentos preferi a morte. Estou destruída" (HATOUM, 2019, p. 288).

Outras imagens importantes aparecem como motivo para panfletar sobre os perigos que rondam estados de exceção, como ocorre na carta da personagem Nortista a Martim: "Penso no sofrimento dos pais que desconhecem o paradeiro de um filho, na angústia dos filhos que não sabem o destino da mãe ou do pai. Essa é a tua história, e a de tantos pais e filhos" (HATOUM, 2019, p. 291). Na mesma carta, a personagem relata a imagem da tortura que horroriza e ratifica a importância de combater torturadores e não os elogiar, como fazem os atuais detentores do poder político nacional:

O militar pegou o volume da tradução francesa das peças de Brecht e começou a arrancar e rasgar lentamente as páginas. Aí cuspiu com ódio o nome de Jorge Alegre. "O dono da livraria", ele disse. "Esse comuna católico faz sermões perigosos em reuniões subversivas [...] Porradas na minha cabeça [...] Me espancava, rasgava páginas do livro de Górki, gozando com riso de carrasco, o olhar frio, brilhante de ódio. O carcereiro não ria, era uma sentinela séria na porta de ferro [...] Uma pessoa pode suportar a dor física até o extremo, um extremo que se dilata até o fim de tudo, quando não se pensa mais em nada, nem mesmo na morte (HATOUM, 2019, p. 294).

Além das imagens de dor e violência física expostas no romance Pontos de fuga, o autor recorre, por meio das reflexões das personagens na obra, às análises acerca do movimento que a política proposta pela ultradireita brasileira, demonstrando aquilo que considera como erros da anistia nacional, que declara ser um acordo infeliz, por ter sepultado a possibilidade do Brasil aprender definitivamente com seu passado e não repetir erros como o que o golpe que objetivou, também nas palavras do autor, o impeachment da presidente Dilma Rousseff, que abriu caminho para a eleição de um elogiador da tortura. A reflexão da personagem Nortista corrobora a preocupação de Hatoum:

Muitos exilados e expatriados já estão por aqui, os movimentos grevistas continuam, os trabalhadores foram reprimidos, vários líderes presos, demissões em massa. Eis a prometida abertura política do generalpresidente, uma cavalgadura tosca, das mais vulgares. Os milicos e civis golpistas estão enfraquecidos, um dia vão cair fora, depois os saudosistas da infâmia vão dar outro bote, com a cumplicidade do Irmão Poderoso do 
Norte. A cada vinte ou trinta anos Moloch troca de máscara, mas mantém a cabeça de ganância e crueldade, e o mesmo ventre, que devora e imola crianças. Serão novos tempos de errância, pesadelos em plena vigília, desonra do corpo e da mente [...] A memória só faz sentido depois do esquecimento? (HATOUM, 2019, p. 309).

O desfecho do romance (ainda que esperemos o terceiro volume da trilogia) já nos antecipa e esclarece tudo aquilo que Hatoum nos pretende mostrar e alertar: a falsidade das estratégias políticas mascaradas, as sombras nas quais se escondem os saudosistas dos regimes de exceção, a ganância cruel dos que oprimem as minorias, nossas errâncias e os poderes da memória e do esquecimento, em tempos tão sombrios, nos quais buscamos pontos de fuga.

\section{CONSIDERAÇÕES FINAIS}

Como vimos, Milton Hatoum sempre declarou não intencionar a utilização de sua obra como manifestação panfletária, mesmo diante de complicados vieses políticos enfrentados no mundo, especialmente no Brasil, nas últimas décadas. Ainda assim, o autor, na contramão de suas próprias declarações, alude em suas entrevistas à necessidade de usar todos os meios possíveis, especialmente em momentos como o atual, para lutar contra a opressão e as mazelas trazidas pelo sistema opressor imposto pelo atual governo Bolsonaro.

Em sua carreira como escritor ficcionista, principalmente por meio de seus romances, o autor produziu obras que abordavam dramas familiares: Relato de um certo Oriente (1989); Dois irmãos (2000); Cinzas do Norte (2005) e Órfãos do Eldorado (2008). Tais romances trazem também, em menor tom e de maneira às vezes sutil, críticas à sociedade e à política nacionais. Ainda que em continuidade ao tema dos desacertos familiares, presente nas obras anteriores, os dois últimos romances de Hatoum A noite da espera (2017) e Pontos de Fuga (2019) - objeto de discussão neste artigo - trazem com mais força o tom de crítica política, especialmente ao período da ditadura militar no Brasil, perfazendo um caminho imaginado pelo autor desde os anos 1980 - a partir de suas próprias vivências como estudante perseguido e preso pelo regime - e introjetado em suas complexas e instigantes personagens.

A partir da análise de diversas entrevistas do autor e investigação de seus textos e biografia, verifica-se sua preocupação constante com os regimes opressores e violentos, seu olhar crítico sobre a perseguição às minorias, liderada pelo atual presidente Jair Bolsonaro, e a luta do autor pela conscientização dos mais jovens, além da conclamação à reflexão crítica. Restou da análise a observação dos períodos históricos de escrita, maturação e publicação do 
romance e a sutil intencionalidade do autor - apesar de sua recusa ao tom panfletário - em publicar um romance tão denso, impactante e importante para a manutenção na memória brasileira acerca dos horrores da ditadura militar e da necessidade de que recusemos, como cidadãos conscientes, os desmandos de governos opressores a degradantes. Tal ação proativa do intelectual demonstra a importância do papel do artista e nos conclama à reflexão sobre o momento histórico atual, na qual os pensadores, cientistas e produtores do conhecimento representam não só um alento, mas um guia para a construção de uma humanidade plena de seus desafios e potencialidades ante à barbárie.

\section{REFERENNCIAS}

ARANDA, Jaynan Borges. Melhor já ir interpretando: Bolsonaro e ofertas de si em vídeos da campanha presidencial de 2018. Trabalho de conclusão de curso. Porto Alegre: UFRGS, 2018.

BAUMAN, Zygmunt. Modernidade líquida. Tradução Plínio Dentzien. Rio de Janeiro: Jorge Zahar, 2001.

BENJAMIN, Walter. Magia e Técnica, arte e política: ensaios sobre literatura e história da cultura. Obras Escolhidas volume 1. Ed. 3. Rio de Janeiro: Brasiliense, 1987.

Charles Baudelaire: um lírico no auge do capitalismo. Obras Escolhidas Vํ. III. São Paulo: Brasiliense, 1989.

EAGLETON, Terry. Teoria da literatura: uma introdução. Tradução de Waltensir Dutra. São Paulo: Martins Fontes, 2006.

HATOUM, Milton. Pontos de fuga. $1^{\text {a }}$ ed. São Paulo: Companhia das Letras, 2019.

. Milton Hatoum: a volta do narrador desgarrado. Entrevista concedida a João Renato Faria - Jornal O Tempo: Belo Horizonte. 2019a. Disponível em: <https://www.otempo.com.br/diversao/milton-hatoum-a-volta-do-narrador-desgarrado$\underline{1.2268210}>$. Acesso em: 23 de jun. 2020.

Milton Hatoum lança 'Pontos de fuga' segunda parte de trilogia. Entrevista concedida ao Jornal Correio Braziliense. 2019b.

Disponível em: <https://www.correiobraziliense.com.br/app/noticia/diversao-earte/2019/10/26/interna_diversao_arte,801052/milton-hatoum-pontos-defuga.shtml\#: :text=Ao\%20lan\%C3\%A7ar\%20'Pontos\%20de\%20fuga,passado\%20n\%C3\% A3o\%20deve\%20ser\%20esquecido'\&text=N\%C3\%A3o\%20\%C3\%A9\%20diferente\%20em \%20Pontos,de\%20A\%20noite\%20da\%20espera. $>$. Acesso em: 22 de jun. 2020.

Milton Hatoum, da literatura à política. Entrevista concedida à Revista Sentido.

[S.I.] [2018?] Disponível em: <http://revistasentido.com/milton-hatoum-da-literatura-a- 
politica/>. Acesso em: 22 de jun. 2020.

. Milton Hatoum: 'Uma literatura ideológica pode enfraquecer o romance'. Entrevista concedida a Valentine Herold - Jornal do Commércio. [S.I.] 2020. Disponível em: <https://jc.ne10.uol.com.br/canal/cultura/literatura/noticia/2020/02/02/milton-hatoumuma-literatura-ideologica-pode-enfraquecer-o-romance-398718.php>. Acesso em: 22 de jun. 2020.

. Uma imersão em tempos sombrios com Milton Hatoum. Entrevista concedida à

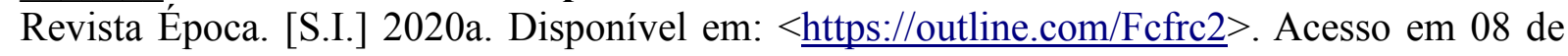
jun. 2020.

'Neste momento, o silêncio é cúmplice', diz o escritor Milton Hatoum. Entrevista concedida a Bruno Mateus do Jornal O Tempo: Belo Horizonte. 2020b. Disponível em: $\quad<$ https://www.otempo.com.br/diversao/neste-momento-o-silencio-e-cumplice-diz-oescritor-milton-hatoum-1.2352294>. Acesso em 08 de jun. 2020.

. Escritor Milton Hatoum avalia como será a vida das pessoas após a pandemia. Entrevista concedida ao Jornal Correio Braziliense: Brasília. 2020c.

Disponível em: $\quad<$ https://www.correiobraziliense.com.br/app/noticia/diversao-earte/2020/05/16/interna_diversao_arte,855408/escritor-milton-hatoum-avalia-como-sera-avida-das-pessoas-apos-a-pand.shtml > . Acesso em 16 de mai. 2020.

ISER, Wolfgang. O ato da leitura: uma teoria do efeito estético, volume I. Tradução de Johannes Kretschmer. São Paulo: Editora 34, 1996.

SAID, Edward. Representações do intelectual, As Conferências Reith de 1993. São Paulo: Editora Companhia das Letras, 2005.

2007.

Humanismo e crítica democrática. São Paulo: Editora Companhia das Letras,

VIEIRA, Estela J. Milton Hatoum e a representação do exótico e do imigrante. In: CRISTO, Maria da Luz Pinheiro de (org.). Arquitetura da memória: ensaios sobre os romances Dois irmãos, Relato de um Certo Oriente e Cinzas do norte de Milton Hatoum. Manaus: Editora da Universidade Federal Amazonas / UNINORTE, 2007.

Recebido: $27 / 07 / 2020$

Aprovado: $14 / 10 / 2020$ 